OPEN ACCESS

Edited by:

Sercan Aksoy,

Hacettepe University, Turkey

Reviewed by:

Deniz Can Guven, Hacettepe University, Turkey

Nuriye Özdemir

Gazi University, Turkey

*Correspondence:

Linda Connelly

connellyl@cusm.org

Specialty section:

This article was submitted to

Women's Cancer,

a section of the journal

Frontiers in Oncology

Received: 07 January 2020 Accepted: 16 March 2020

Published: 07 April 2020

Citation:

Geerts D, Chopra C and Connelly L (2020) Osteoprotegerin: Relationship to Breast Cancer Risk and Prognosis.

Front. Oncol. 10:462.

doi: 10.3389/fonc.2020.00462

\section{Osteoprotegerin: Relationship to Breast Cancer Risk and Prognosis}

\author{
Dirk Geerts ${ }^{1}$, Christina Chopra ${ }^{2}$ and Linda Connelly ${ }^{2 *}$ \\ ${ }^{1}$ Department of Medical Biology, Academic Medical Center Amsterdam, Amsterdam, Netherlands, ${ }^{2}$ School of Medicine, \\ California University of Science and Medicine, San Bernardino, CA, United States
}

Osteoprotegerin (OPG) is a secreted member of the Tumor Necrosis Factor (TNF) receptor superfamily (TNFRSF11B), that was first characterized and named for its protective role in bone remodeling. In this context, OPG binds to another TNF superfamily member Receptor Activator of NF-kappaB Ligand (RANKL; TNFSF11) and blocks interaction with RANK (TNFRSF11A), preventing RANKL/RANK stimulation of osteoclast maturation, and bone breakdown. Further studies revealed that OPG protein is also expressed by tumor cells and led to investigation of the role of OPG in tumor biology. An increasing body of data has demonstrated that OPG modulates breast tumor behavior. Initially, research was focused on OPG in the bone microenvironment as a potential inhibitor of RANKL-driven osteolysis. More recently, attention has shifted to include OPG expression and interactions in the primary breast tumor independent of RANKL. In the primary tumor, OPG may interact with another TNF superfamily member, TNF-Related Apoptosis Inducing Ligand (TRAIL; TNFSF10) to prevent apoptosis induction. Additional interest in OPG in breast cancer has been stimulated by the tumor-promoting role of its binding partner RANKL in association with BRCA1 gene mutations. We and others have previously summarized the functional studies on OPG and breast cancer (1, 2). After basic research studies on the in vitro role for OPG (and RANKL) in breast cancer, the field now expands to assess the in vivo role for OPG by examining the correlation between OPG expression and breast cancer risk or patient prognosis. However, the data reported so far is conflicting, since OPG expression appears linked to both good and poor patient survival. In the current review we will summarize these studies. Our goal is to provide stimulus for further research to bridge the basic research findings and clinical data regarding OPG in breast cancer.

Keywords: osteoprotegerin (OPG), TNFRSF11B, breast cancer, risk, prognosis, TNF superfamily

\section{INTRODUCTION}

Osteoprotegerin (OPG; encoded by the TNFRSF11B gene) is a secreted member of the TNF receptor protein superfamily that was first characterized and named for its protective role in bone remodeling $(3,4)$. OPG acts as a decoy receptor for Receptor Activator of NF-kappaB Ligand (RANKL; TNFSF11), blocking interaction with RANK (TNFRSF11A) and thereby stimulation of osteoclast maturation. It was subsequently discovered that OPG is expressed by breast tumor cells, including human cancer cell lines and tissue samples (5). OPG also interacts with another TNF superfamily member, TNF-Related Apoptosis Inducing Ligand (TRAIL; TNFSF10), blocking 
induction of apoptosis $(5,6)$. In the 15 years since the first report of OPG expression in breast tumor tissue, a growing number of studies have investigated a mechanistic role for OPG in breast tumorigenesis. These studies have been previously reviewed by our group as well as others $(1,2,7)$. Here we will focus on the clinical studies regarding OPG expression and links to breast cancer risk and prognosis in breast cancer patients. Clarifying the role of OPG in breast cancer patients will validate current research findings and define the questions for future mechanistic studies.

\section{OPG LEVELS AND BREAST CANCER RISK}

Three types of studies with regards to OPG and breast cancer risk exist. One type has focused on Single Nucleotide Polymorphisms (SNPs) in the OPG gene in association with breast cancer. Another type of study has determined whether OPG protein levels correlate with breast cancer risk. The third type of study has investigated OPG protein levels and breast cancer risk in association with BRCA mutations. The findings from each of these studies are described below.

\section{SNPs and Breast Cancer Risk}

TNFRSF11B/OPG is a single copy gene located on chromosome $8 \mathrm{q} 23-34$, that spans $29 \mathrm{~kb}$ and consists of 5 exons (8). Studies on the OPG gene and breast cancer risk have focused on 3 SNPs rs3102735, rs2073617, and rs2073618 (for all SNP annotations see https://www.ncbi.nlm.nih.gov/snp/). The rs3102735 SNP (major allele T, minor allele C) and rs2073617 SNP (major allele T, minor allele C) are in the $5^{\prime}$ promoter region of the OPG gene $(9,10)$. The rs2073618 OPG SNP (major allele G, minor allele C) is in the first exon of OPG with the minor allele $C$ causing the third amino acid in the OPG protein to change from Lysine to Asparagine (11).

Ney et al. (12) studied the frequency of two OPG gene SNPs (rs3102735 and rs2073618) in 614 breast cancer patients and 784 healthy subjects. They found that the minor allele C of SNP rs3102735 was associated with a 1.5-fold increased risk for breast cancer. They did not find an association between the OPG gene SNP rs2073618 and breast cancer risk, but did establish that the major allele $\mathrm{G}$ was more likely to be found in invasive vs. noninvasive breast cancer cases (12). Ney et al. did not measure OPG protein serum levels, but studies on the same SNPs for different disease states did not find differences in OPG serum levels associated with SNPs rs3102735 or rs2073618 $(13,14)$.

A second group investigated associations of OPG gene SNPs rs2073618 and rs2073617 with breast cancer in 176 breast cancer patients and 100 healthy subjects. Unlike the study by Ney et al. described above, this study found that the SNP rs2073618 minor allele $\mathrm{C}$ was more frequent in breast cancer patients than in the control group (15). OPG serum levels in breast cancer patients and healthy subjects were not associated with SNP rs2073618 (15). An increased frequency of the major T allele in the OPG gene SNP rs2073617 was also observed in breast cancer patients as compared to the control group, again with no significant difference in OPG serum levels. These findings on SNPs rs2073618 and rs2073617 allele frequency and increased
TABLE 1 | Summary of studies regarding SNPs in the OPG gene and links to breast cancer.

\begin{tabular}{|c|c|c|}
\hline Study & Genomic DNA from & SNP analysis and findings \\
\hline Ney et al. (12) & $\begin{array}{l}614 \text { breast cancer patients } \\
784 \text { healthy subjects }\end{array}$ & $\begin{array}{l}\text { rs3102735 - Minor C allele, } \\
1.5 x \text { increased risk for breast } \\
\text { cancer } \\
\text { rs2073618 - No association }\end{array}$ \\
\hline $\begin{array}{l}\text { Omar et al. (15) } \\
\text { Shaker et al. (16) }\end{array}$ & $\begin{array}{l}176 \text { breast cancer patients } \\
100 \text { healthy subjects } \\
115 \text { breast cancer patients } \\
120 \text { healthy subjects }\end{array}$ & $\begin{array}{l}\text { rs2073618 - Minor C allele } \\
\text { more frequent in breast } \\
\text { cancer patients } \\
\text { rs2073617 - Major T allele } \\
\text { more frequent in breast } \\
\text { cancer patients }\end{array}$ \\
\hline
\end{tabular}

breast cancer risk were confirmed in a recent study of 115 breast cancer patients and 120 healthy subjects (16). In addition, a combined genotype of heterozygous for the GG major allele for OPG rs2073618 and the CC minor allele for OPG rs2073617 was shown to be protective against the breast cancer (16).

In summary, these studies demonstrate that OPG gene SNPs are associated with breast cancer risk (Table 1). The lack of differences in OPG serum levels would suggest that the effect of SNPs may be related to a change in protein activity, not expression level. However, additional studies on genotype and subsequent phenotype are required before conclusions can be drawn as to pro- or anti-tumor effects of OPG SNPs.

\section{OPG Protein Serum Levels and Breast Cancer Risk}

OPG serum levels and breast cancer risk were initially examined in a large study which recruited 6,279 subjects (male and female) in Norway with no previous history of cancer (17). Serum samples were collected from each participant and frozen for the duration of the study (12 years) before measurement of OPG by ELISA. Nine hundred forty-eight participants developed cancer, of which 76 got breast cancer. Thirty cases of breast cancer were reported in the 1 st Tertile of OPG serum group (0.46$2.78 \mathrm{ng} / \mathrm{ml}), 26$ breast cancer cases for the 2 nd Tertile of OPG serum group $(2.79-3.55 \mathrm{ng} / \mathrm{ml})$ and 20 breast cancer cases for the 3rd Tertile of OPG serum group (3.56-25.81 ng/ml). Based on this, it was calculated that women in the upper Tertile of serum OPG had a $45 \%$ lower relative risk of breast cancer compared to women in the 1st Tertile. Further analysis revealed that there was a $76 \%$ reduction in relative risk with high OPG levels when samples were analyzed in women below 60 years of age.

OPG expression vs. breast cancer risk has been analyzed in a more recent, similar type of study (18). The European Prospective Investigation into Cancer and Nutrition (EPIC) cohort was a study designed to identify risk factors for cancer. From the 235,607 women who participated in this study, 2008 serum samples were analyzed for OPG expression from women who subsequently developed breast cancer alongside a group of matched healthy subjects. Of the 2008 cancer cases, $81 \%$ were Estrogen Receptor positive (ER+) and 19\% were ER negative (ER-). The samples were organized into Tertiles based on the OPG serum levels determined at the start of the study before 
patients developed breast cancer: T1 $=<0.18 \mathrm{ng} / \mathrm{ml}$, T2 $=0.18-$ $<0.22 \mathrm{ng} / \mathrm{ml}$, and T3 $=\geq 0.22 \mathrm{ng} / \mathrm{ml}$. Women with higher OPG serum levels had an increased relative risk (1.93) of risk for ERbreast cancer (T1-82, T2-78, T3-98 cases). There was a modest reduction in risk (0.84) of ER+ breast cancer with high OPG (T1-342, T2-297, T3-290 cases). When comparing these data with Vik et al. it appears that the range of OPG values are much lower in the Fortner et al. study $(17,18)$. The Vik et al. study. Tertiles look at OPG levels from 0.46 to $25.81 \mathrm{ng} / \mathrm{ml}$ while the Fortner et al. study looks at OPG levels from $0.18 \mathrm{ng} / \mathrm{ml}$ and below to above $0.22 \mathrm{ng} / \mathrm{ml}$. The Fortner study reports a difference between ER+ and ER- samples, while ER status was not assigned in the Vik et al. study. Based on common findings, it is likely that the predominant subtype in 76 patients in the Vik et al. study would be ER+, and then there would be agreement in the association of low OPG serum levels with reduced risk for ER+ breast cancer (19).

In the only other study examining breast cancer risk, OPG serum levels were measured in a group of 278 postmenopausal women (20). The group was subsequently stratified as to whether they developed breast cancer within 12 months (40 women) or within 12-24 months (58 women), while the women that did not develop breast cancer during follow up were used as healthy subjects (180 women). Serum OPG levels ranged from $0.60-$ $9.91 \mathrm{pM}$. There were no differences in serum OPG levels in the women who developed breast cancer within 12-24 months as compared to healthy subjects. However, in the group that developed breast cancer within 12 months, serum OPG levels were higher than in healthy subjects. It should be noted that tumor development in the 12 months prior to detection could lead to OPG protein production by tumor cells. Therefore, this data may not necessarily reflect OPG levels and "breast cancer risk".

Another study followed up on women in the EPIC cohort who developed breast cancer and analyzed risk of death following a breast cancer diagnosis in relation to pre-diagnosis OPG serum levels and ER subtype in 2006 women (21). There was an increased risk of breast cancer-specific mortality in women with ER+ disease who had higher pre-diagnosis OPG serum levels (Quintile $5>12.38 \mathrm{pM}$ as compared to Quintile $1 \leq$ $7.80 \mathrm{pM})$. OPG levels were not associated with mortality risk in women with ER- breast cancer. Therefore, while the previous study by this group in the EPIC cohort linked high OPG with a slightly reduced risk for ER+ breast cancer, after breast cancer development, higher OPG levels correlate with poorer prognosis in this patient group.

\section{OPG and Breast Cancer Risk With BRCA Mutations}

RANKL plays a role in the breast cancer development signaling in patients with BRCA1 mutations (22). The ability of OPG to bind to RANKL and block its activity raised interest in the role of OPG in BRCA1-mutated breast cancer. Serum OPG levels were measured in 391 BRCA1 or-2 mutation carriers and 782 noncarrier healthy subjects. BRCA mutation carriers were found to have lower OPG serum levels than healthy subjects [range of
TABLE 2 | Summary of studies investigation associations between OPG and breast cancer risk.

\begin{tabular}{|c|c|c|c|}
\hline Study & Participants & $\begin{array}{l}\text { OPG } \\
\text { Analysis }\end{array}$ & Significant data \\
\hline Vik et al. (17) & 76 women & Serum & $\begin{array}{l}\text { Reduced breast cancer } \\
\text { risk with high OPG } \\
\text { expression }\end{array}$ \\
\hline Kiechl et al. (20) & $\begin{array}{l}278 \text { post-menopausal } \\
\text { women }\end{array}$ & Serum & $\begin{array}{l}\text { High OPG expression } \\
\text { associated with breast } \\
\text { cancer development } \\
\text { within } 12 \text { months }\end{array}$ \\
\hline $\begin{array}{l}\text { Fortner et al. } \\
(18)\end{array}$ & $\begin{array}{l}2008 \text { women (EPIC } \\
\text { cohort) }\end{array}$ & Serum & $\begin{array}{l}\text { High OPG expression } \\
\text { associated with } \\
\text { increased risk for ER- } \\
\text { breast cancer, } \\
\text { suggestive inverse } \\
\text { association for ER+ }\end{array}$ \\
\hline Sarink et al. (21) & $\begin{array}{l}2006 \text { women (EPIC } \\
\text { cohort) }\end{array}$ & Serum & $\begin{array}{l}\text { High OPG expression } \\
\text { associated with } \\
\text { increased mortality in } \\
\text { ER+ breast cancer }\end{array}$ \\
\hline $\begin{array}{l}\text { Widschwendter } \\
\text { et al. (24) }\end{array}$ & $\begin{array}{l}391 \text { BRCA1/2 } \\
\text { mutation carriers } \\
782 \text { healthy subjects }\end{array}$ & Serum & $\begin{array}{l}\text { BRCA mutation carriers } \\
\text { had lower OPG } \\
\text { expression }\end{array}$ \\
\hline Oden et al. (23) & $\begin{array}{l}206 \text { BRCA1/2 } \\
\text { mutation carriers }\end{array}$ & Serum & $\begin{array}{l}\text { Lower OPG expression } \\
\text { in women that later } \\
\text { developed breast } \\
\text { cancer }\end{array}$ \\
\hline
\end{tabular}

values studied were 10.8 to $1,414 \mathrm{pg} / \mathrm{ml}$ (23)]. This study did not include a follow up to determine whether low OPG levels linked to breast cancer risk.

In a subsequent study, 206 women with BRCA1 or-2 mutations had serum OPG levels measured, were divided into low OPG (mean $62.9 \mathrm{pg} / \mathrm{ml}$; range $4.2-94.5 \mathrm{pg} / \mathrm{ml}$ ) or high OPG (mean $168.1 \mathrm{pg} / \mathrm{ml}$; range $95.5-547.7 \mathrm{pg} / \mathrm{ml}$ ) groups, and were followed for the development of breast cancer. Within 6.5 years, 13 of 103 women in the low OPG group developed breast cancer, compared with 6 of 103 women in the high OPG group (23). Overall, the women who developed breast cancer had lower baseline OPG serum levels (mean $90.59 \mathrm{pg} / \mathrm{ml}$; range 4.2$205.7 \mathrm{pg} / \mathrm{ml}$ ) compared to women who did not develop breast cancer (mean $117.9 \mathrm{pg} / \mathrm{ml}$; range $7.4-547.7 \mathrm{pg} / \mathrm{ml}$ ). The authors acknowledged that this was a small study, and that the effects observed were only marginally significant.

In summary, the limited studies in this area so far do not establish a clear link between OPG serum levels and breast cancer risk in BRCA mutation carriers. Additional studies are needed to establish whether these are indeed linked. The implications of these studies also need to be considered in light of the high breast cancer risk in this patient population.

In the studies on breast cancer risk we discussed, OPG expression was characterized as serum OPG levels. These studies are summarized in Table 2. In marked contrast, the studies that analyzed OPG expression in association with prognosis described below mainly consider OPG expression in the primary breast tumor. 


\section{OPG EXPRESSION AND BREAST CANCER PATIENT PROGNOSIS}

The initial studies on OPG expression in patient samples were performed by IHC (immunohistochemistry) on breast tumor tissues. In a study of 400 patient samples, lower OPG protein expression was observed with increasing tumor grade $(5,25)$. OPG protein expression was higher in ER+ samples than in ER-samples $(5,25,26)$.

Subsequent studies on OPG expression in breast cancer patients were performed using microarray data of OPG mRNA expression in breast cancer tissues. Santini et al. examined OPG expression in a publicly available dataset of 295 primary breast cancer patients (27). In contrast to the earlier work by Holen et al. this study found no significant difference in OPG mRNA expression between ER+ and ER- tissue samples. There was also no difference in OPG mRNA expression in relation to primary tumor size ( $<$ or $>2 \mathrm{~cm}$ ). However, in agreement with the earlier immunohistochemical data, lower OPG mRNA expression was observed with increasing tumor grade. This study also separated patients into "good" and "poor" prognosis groups and found that there was a significant association of higher OPG mRNA expression with "good" prognosis. Furthermore, Kaplan-Meier analysis showed that patients with high primary tumor OPG mRNA expression had increased disease free survival (DFS) and overall survival (OS).

Owen et al. analyzed OPG mRNA expression by quantitative RT-PCR in 127 breast cancer tissues and 31 non-neoplastic control breast tissues (28). They did not find significant differences in OPG mRNA expression in tumor vs. normal samples or in ER+ vs. ER- samples. Kaplan-Meier analyses, in contrast to the Santini et al. data, showed that patients with higher OPG mRNA expression had significantly poorer OS (108 vs. 142 months).

These initial studies show varying effects. Further studies on OPG expression and breast cancer prognosis share this pattern. Indeed, having found discordant results in microarray analysis for OPG mRNA expression in a small number of breast cancer data sets, Sanger et al. expanded their study to 40 publicly available breast cancer microarray datasets [4,467 samples; (29)]. The patient samples with high OPG mRNA expression levels were less likely to be ER+, but more likely to be Progesterone Receptor positive. This is in contrast to the study by Holen et al. that linked high OPG expression with ER+ samples by IHC (5). OPG expression was associated with a better prognosis in ER+ tumors but there was no significant prognostic value for OPG in the ER- group (29). It should be noted that when the datasets were studied individually, only 7 of 18 ER+ groups showed a significant effect or trend for better prognosis with high OPG, 11 of 18 showed no difference in patient survival.

Park et al. studied 175 breast tumor tissue samples by IHC on tissue microarray blocks and stratified into patients with (85 patients) and without (90 patients) tumor OPG expression (30). In agreement with the previous two studies that linked a reduced OPG expression levels with increasing tumor grade, patients with larger tumors $(>2 \mathrm{~cm})$ or T4 tumors [tumors of any size growing into the chest wall or skin; (31)] were less likely to have tumor OPG expression than patients with smaller tumors. A lack of OPG expression was also associated with lymph node involvement and higher proliferation index as measured by Ki67 staining. Patients with OPG-expressing tumors were more likely to undergo breast-conserving surgery (as opposed to mastectomy) than those with OPG-negative tumors. Despite these suggestions that OPG expression was correlated to good prognosis, no link was found between OPG expression and disease free or OS or ER status.

Two studies by Labovsky et al. $(32,33)$ examined OPG expression by IHC in 63 tissue biopsies from patients with breast cancer. They found that OPG expression was higher in the breast tumors as compared to 10 non-neoplastic control breast tissues (32). In addition, OPG expression in spindle-shaped stromal cells within the tumors was associated with metastasis (33). The authors proposed that the spindle-shaped cells were tumor-recruited mesenchymal stem cells with metastasispromoting function.

Luo et al. performed a study using publicly available breast tumor microarray data (546 samples) and breast tumor biopsies [86 samples; (34)]. Kaplan Meier analysis showed that high OPG expression was associated with increased OS and increased distant metastasis-free survival in both data sets. No significant effect was observed for OPG expression in relation to lung metastasis-free survival. IHC on the breast tumor biopsies showed that OPG expression was down-regulated in breast tumors as compared with adjacent normal tissue.

In another study on publicly available tumor sample data, Vidula et al. used microarray analysis on pre-treatment biopsies taken from 149 patients in the I-SPY 1 trial (patients with at least $3 \mathrm{~cm}$ invasive breast cancer with no distant metastases) and a dataset from 425 pre-treatment biopsies (35). In the ISPY1 tissue samples, OPG expression was higher in HER2vs. HER2 + samples. OPG expression was also higher in Stage I/II than in Stage III and inflammatory tumors, and higher in Grade I than in Grade II/III tumors. However, they found no significant correlation between OPG expression and RFS (relapse free survival) in either data set.

Timotheadou et al. performed quantitative RT-PCR on 814 breast cancer tissue samples before adjuvant therapy (36). They found high OPG mRNA expression was associated with the Luminal A breast cancer subtype. Low OPG mRNA expression was associated with higher histological tumor grade, and with radical mastectomy. This study did not identify a significant association between OPG expression and DFS or OS.

While the studies discussed so far have analyzed OPG mRNA or protein expression in the breast tumors in association with prognosis, a recent study has looked at OPG serum levels in breast cancer patients. Rachner et al. measured serum OPG in 504 patients with primary, non-metastatic breast cancer (37). They found that high serum OPG levels were associated with lower survival in Kaplan Meier analysis. The mean serum OPG levels in this study were $4.24 \pm 1.68 \mathrm{pM}$ (range $0.46-13.40 \mathrm{pM}$ ) and $81 \%$ of the patients had ER+ disease. Given the ability of OPG to exert a "protective" effect in bone, the authors also examined the presence of bone metastases. They found no association between serum OPG levels and bone metastasis development. 
TABLE 3 | Summary of studies regarding OPG and breast cancer prognosis.

\begin{tabular}{|c|c|c|c|}
\hline Study & Tissues/Subjects & OPG analysis & Significant data \\
\hline $\begin{array}{l}\text { Holen et al. (5) and Cross et al. } \\
\text { (25) }\end{array}$ & 400 breast tumors & $\begin{array}{l}\text { Protein } \\
\mathrm{IHC}\end{array}$ & $\begin{array}{l}\text { - OPG expression lower with increasing tumor grade } \\
\text { - OPG expression lower in ER- than ER+ tumors }\end{array}$ \\
\hline Van Poznak et al. (26) & 40 breast tumors & $\begin{array}{l}\text { Protein } \\
\mathrm{IHC}\end{array}$ & - Correlation between OPG expression and ER/PR status \\
\hline $\begin{array}{l}\text { Santini et al. ( } 27) \\
\text { OPG }=\text { good prognosis }\end{array}$ & 295 breast tumors & $\begin{array}{l}\text { RNA } \\
\text { Microarray }\end{array}$ & $\begin{array}{l}\text { - OPG expression associated with good prognosis } \\
\text { - High OPG expression associated with increased DFS and OS } \\
\text { - No difference ER+ vs. ER- }\end{array}$ \\
\hline $\begin{array}{l}\text { Owen et al. (28) } \\
\text { OPG = poor prognosis }\end{array}$ & $\begin{array}{l}127 \text { breast tumors } \\
31 \text { matching normal tissues }\end{array}$ & $\begin{array}{l}\text { RNA } \\
\text { qRT-PCR }\end{array}$ & - High OPG expression associated with significantly poorer OS \\
\hline $\begin{array}{l}\text { Sanger et al. (29) } \\
\text { OPG = good prognosis }(E R+)\end{array}$ & 4,467 breast tumors & $\begin{array}{l}\text { RNA } \\
\text { Microarray }\end{array}$ & $\begin{array}{l}\text { - OPG expression lower in ER+ } \\
\text { - OPG expression associated with better prognosis in ER+ }\end{array}$ \\
\hline $\begin{array}{l}\text { Park et al. (30) } \\
\text { No link }\end{array}$ & 175 breast tumors & $\mathrm{IHC}$ & $\begin{array}{l}\text { - Lower OPG expression with increasing tumor grade } \\
\text { - OPG expression associated with lack of lymph node involvement } \\
\text { and lower proliferation index } \\
\text { - No link OPG expression with DFS/OS }\end{array}$ \\
\hline $\begin{array}{l}\text { Labovsky et al. }(32,33) \\
\text { OPG associated with metastasis }\end{array}$ & $\begin{array}{l}63 \text { breast tumors } \\
10 \text { non-neoplastic } \\
\text { control tissues }\end{array}$ & $\mathrm{IHC}$ & $\begin{array}{l}\text { - Higher OPG expression in breast tumors than in healthy tissue } \\
\text { - OPG expression in spindle-shaped stromal cells from breast } \\
\text { tumors associated with presence of metastasis }\end{array}$ \\
\hline $\begin{array}{l}\text { Luo et al. (34) } \\
\text { OPG = good prognosis }\end{array}$ & $\begin{array}{l}546 \text { breast tumors dataset } \\
86 \text { breast tumors }\end{array}$ & $\begin{array}{l}\text { RNA } \\
\text { Microarray } \\
\text { IHC }\end{array}$ & $\begin{array}{l}\text { - High OPG expression associated with increased OS and distant } \\
\text { metastasis free survival } \\
\text { - } I H C \text { showed } \\
\text { OPG down-regulated in breast tumors compared to } \\
\text { adjacent tissue }\end{array}$ \\
\hline $\begin{array}{l}\text { Vidula et al. (35) } \\
\text { No link }\end{array}$ & $\begin{array}{l}149 \text { I-SPY1 breast tumors } \\
425 \text { breast tumor dataset } \\
\text { (all pre-treatment) }\end{array}$ & $\begin{array}{l}\text { RNA } \\
\text { Microarray }\end{array}$ & $\begin{array}{l}\text { - Higher OPG expression in HER2- vs. HER+ } \\
\text { - Higher OPG expression in lower stage and grade of tumor } \\
\text { - No significant effect on relapse free survival }\end{array}$ \\
\hline $\begin{array}{l}\text { Timotheadou et al. (36) } \\
\text { No link }\end{array}$ & 814 breast tumors & $\begin{array}{l}\text { RNA } \\
\text { qRT-PCR }\end{array}$ & $\begin{array}{l}\text { - Higher OPG expression associated with luminal A subtype } \\
\text { - Low OPG expression associated with modified radical } \\
\text { mastectomy and higher histological grade } \\
\text { - No association between OPG and DFS/OS }\end{array}$ \\
\hline $\begin{array}{l}\text { Rachner et al. (37) } \\
\text { OPG = poor prognosis }\end{array}$ & $\begin{array}{l}504 \text { primary, non-metastatic } \\
\text { breast cancer patients }\end{array}$ & Serum & - High OPG serum levels associated with poorer survival \\
\hline
\end{tabular}

Studies which present data in relation to prognosis are highlighted as good prognosis (yellow), poor prognosis (blue), and no link to prognosis (green).

\section{DISCUSSION}

The studies published so far present varied conclusions: 3 studies find OPG expression associated with better prognosis, 3 find OPG expression associated with poor prognosis, and 3 found no link between OPG and prognosis (Table 3). However, it should be noted that 5 of the studies reported that OPG tumor expression decreased with increasing tumor grade as the most consistent finding across the datasets. Future studies may want to take this characteristic into account when analyzing their data. There is currently limited understanding regarding regulation of OPG expression in breast cancer, and the mechanism by which OPG expression changes with tumor grades is unknown. We have reported that there is an increase in OPG gene copy number in breast cancers and that this increase correlates with poor survival (38). In addition, we have shown that OPG expression is up-regulated in breast cancer cells cocultured with macrophages and this is in part due to the presence of Interleukin 1Beta (39). These studies demonstrate the potential for increased OPG expression in breast cancer, but the mechanisms for down-regulation with increasing tumor grade require further investigation.
The majority of the studies on OPG expression and prognosis have analyzed mRNA expression. Recently Rachner et al. took a different approach and measured OPG serum levels (37). Here they found that high OPG serum levels correlated with reduced survival for breast cancer patients. This data agrees with the breast cancer risk studies which found that high serum OPG levels before breast cancer diagnosis was associated with increased risk as well as higher mortality following diagnosis. Further measurements of OPG serum levels are required to validate prognostic effects once breast cancer has developed.

Several of the studies observe differences in effects of OPG in relation to ER+ or ER- subtypes. Only limited mechanistic studies exist on the link between OPG expression and ER status. Treatment of ER+ breast cancer cells with 17Beta-Estradiol in vitro resulted in decreased OPG mRNA and protein expression (40). We analyzed OPG mRNA expression in datasets from breast cancer cell lines and found that OPG expression was higher in basal as compared to luminal cell lines (38). Further analysis is required to determine the association between OPG expression and ER status in breast tumor samples.

An analysis of the variable results of studies into the role of OPG in breast cancer risk and prognosis must also reflect on the 
current status of the signal transduction literature. OPG has the potential to interact with RANKL, which exerts primary tumorpromoting and metastasis-promoting roles in breast cancer $(3,4$, 41, 42). OPG-mediated blocking of RANKL signaling in breast cancer would likely have an anti-tumor effect and result in a better prognosis. However, OPG has also been described to interact with TRAIL and thereby prevent induction of apoptosis in tumor cells $(5,6)$. In this context, OPG would have a tumorpromoting effect and thus be associated with a poorer prognosis. OPG may also interact with other, as yet uncharacterized, ligands, and receptors within the breast tumor microenvironment. OPG must therefore also be considered in an environmental context - actions of OPG in the primary tumor have been reported to be tumor-promoting while studies that focus on the bone microenvironment show anti-tumor effects $(38,39,42-44)$. In a previous study, our group has inoculated OPG knockdown cells in a chick embryo metastasis model and observed a reduction in the ability of cells to metastasize to the chick tissues (38). In contrast, administration of recombinant OPG-Fc reduced the growth of bone tumors in a murine model (44). Interestingly, these contrasting effects of OPG were illustrated in a study by Zinonos et al. where OPG-overexpressing breast cancer cells were introduced in a murine model by intra-tibial injection. While the overexpression of OPG limited tumor growth and

\section{REFERENCES}

1. Goswami S, Sharma-Walia N. Osteoprotegerin rich tumor microenvironment: implications in breast cancer. Oncotarget. (2016) 7:42777-91. doi: 10.18632/oncotarget.8658

2. Weichhaus M, Chung ST, Connelly L. Osteoprotegerin in breast cancer: beyond bone remodeling. Mol Cancer. (2015) 14:117. doi: 10.1186/s12943-015-0390-5

3. Simonet WS, Lacey DL, Dunstan CR, Kelley M, Chang MS, Luthy R, et al. Osteoprotegerin: a novel secreted protein involved in the regulation of bone density. Cell. (1997) 89:309-19. doi: 10.1016/S0092-8674(00)80209-3

4. Tsuda E, Goto M, Mochizuki S, Yano K, Kobayashi F, Morinaga T, et al. Isolation of a novel cytokine from human fibroblasts that specifically inhibits osteoclastogenesis. Biochem Biophys Res Commun. (1997) 234:137-42. doi: 10.1006/bbrc.1997.6603

5. Holen I, Cross SS, Neville-Webbe HL, Cross NA, Balasubramanian SP, Croucher PI, et al. Osteoprotegerin (OPG) expression by breast cancer cells in vitro and breast tumours in vivo-a role in tumour cell survival? Breast Cancer Res Treat. (2005) 92:207-15. doi: 10.1007/s10549-005-2419-8

6. Rachner TD, Benad P, Rauner M, Goettsch C, Singh SK, Schoppet M, et al. Osteoprotegerin production by breast cancer cells is suppressed by dexamethasone and confers resistance against TRAIL-induced apoptosis. $J$ Cell Biochem. (2009) 108:106-16. doi: 10.1002/jcb.22232

7. Infante $M$, Fabi A, Cognetti F, Gorini S, Caprio M, Fabbri A. RANKL/RANK/OPG system beyond bone remodeling: involvement in breast cancer and clinical perspectives. J Exp Clin Cancer Res. (2019) 38:12. doi: 10.1186/s13046-018-1001-2

8. Morinaga $\mathrm{T}$, Nakagawa $\mathrm{N}$, Yasuda $\mathrm{H}$, Tsuda $\mathrm{E}$, Higashio $\mathrm{K}$. Cloning and characterization of the gene encoding human osteoprotegerin/osteoclastogenesis-inhibitory factor. Eur J Biochem. (1998) 254:685-91. doi: 10.1046/j.1432-1327.1998.2540685.x

9. Arko B, Prezelj J, Komel R, Kocijancic A, Hudler P, Marc J. Sequence variations in the osteoprotegerin gene promoter in patients with postmenopausal osteoporosis. J Clin Endocrinol Metab. (2002) 87:4080-4. doi: 10.1210/jc.2002-020124

10. Langdahl BL, Carstens M, Stenkjaer L, Eriksen EF. Polymorphisms in the osteoprotegerin gene are associated with osteoporotic fractures. J Bone Miner Res. (2002) 17:1245-55. doi: 10.1359/jbmr.2002.17.7.1245 bone loss in the bone microenvironment, there was a significant increase in the incidence of pulmonary metastasis (45). Given these opposing effects, it is likely that OPG expression could both be a benefit and a risk to the breast cancer patient, possibly with the opposing effects occurring at different stages and different sites in the disease process. Thus, the varying correlations of OPG with prognosis, as reported this far, are perhaps not so surprising. Therefore, we conclude that further investigation is needed on the biological effects of OPG at different stages of breast cancer and that an integration of the signaling and clinical study data is necessary to fully understand the role of OPG in breast cancer.

\section{AUTHOR CONTRIBUTIONS}

DG and LC conceptualized the manuscript, conducted literature searches, analyzed and interpreted the literature and drafted the manuscript. CC conducted literature searches, categorized the papers and assisted with editing the manuscript. All authors read and approved the manuscript.

\section{ACKNOWLEDGMENTS}

DG dedicates this to Monique Keijzer for her courage and inspiration.

11. Zhao HY, Liu JM, Ning G, Zhao YJ, Zhang LZ, Sun LH, et al. The influence of Lys3Asn polymorphism in the osteoprotegerin gene on bone mineral density in Chinese postmenopausal women. Osteoporos Int. (2005) 16:151924. doi: 10.1007/s00198-005-1865-9

12. Ney JT, Juhasz-Boess I, Gruenhage F, Graeber S, Bohle RM, Pfreundschuh M, et al. Genetic polymorphism of the OPG gene associated with breast cancer. BMC Cancer. (2013) 13:40. doi: 10.1186/1471-2407-13-40

13. Bonfa AC, Seguro LP, Caparbo V, Bonfa E, Pereira RM. RANKL and OPG gene polymorphisms: associations with vertebral fractures and bone mineral density in premenopausal systemic lupus erythematosus. Osteoporos Int. (2015) 26:1563-71. doi: 10.1007/s00198-015-3029-x

14. Xue JB, Zhan XL, Wang WJ, Yan YG, Liu C. OPG rs2073617 polymorphism is associated with upregulated OPG protein expression and an increased risk of intervertebral disc degeneration. Exp Ther Med. (2016) 12:702-10. doi: 10.3892/etm.2016.3342

15. Omar HS, Shaker OG, Nassar YH, Marzouk SA, ElMarzouky MS. The association between RANKL and osteoprotegerin gene polymorphisms with breast cancer. Mol Cell Biochem. (2015) 403:219-29. doi: 10.1007/s11010-015-2352-z

16. Shaker OG, Senousy MA. Association of SNP-SNP interactions between RANKL, OPG, CHI3L1, and VDR genes with breast cancer risk in Egyptian women. Clin Breast Cancer. (2019) 19:e220-e38. doi: 10.1016/j.clbc.2018.09.004

17. Vik A, Brodin EE, Mathiesen EB, Brox J, Jorgensen L, Njolstad I, et al. Serum osteoprotegerin and future risk of cancer and cancer-related mortality in the general population: the tromso study. Eur J Epidemiol. (2015) 30:219-30. doi: 10.1007/s10654-014-9975-3

18. Fortner RT, Sarink D, Schock H, Johnson T, Tjonneland A, Olsen A, et al. Osteoprotegerin and breast cancer risk by hormone receptor subtype: a nested case-control study in the EPIC cohort. BMC Med. (2017) 15:26. doi: 10.1186/s12916-017-0786-8

19. Russnes HG, Lingjaerde OC, Borresen-Dale AL, Caldas C. Breast cancer molecular stratification: from intrinsic subtypes to integrative clusters. Am J Pathol. (2017) 187:2152-62. doi: 10.1016/j.ajpath.2017.04.022

20. Kiechl S, Schramek D, Widschwendter M, Fourkala EO, Zaikin A, Jones A, et al. Aberrant regulation of RANKL/OPG in women at high risk of developing breast cancer. Oncotarget. (2017) 8:3811-25. doi: 10.18632/oncotarget.14013 
21. Sarink D, Schock H, Johnson T, Chang-Claude J, Overvad K, Olsen A, et al. Receptor activator of nuclear factor $\mathrm{kB}$ ligand, osteoprotegerin, and risk of death following a breast cancer diagnosis: results from the EPIC cohort. BMC Cancer. (2018) 18:1010. doi: 10.1186/s12885-018-4887-3

22. Nolan E, Vaillant F, Branstetter D, Pal B, Giner G, Whitehead L, et al. RANK ligand as a potential target for breast cancer prevention in BRCA1-mutation carriers. Nat Med. (2016) 22:933-9. doi: 10.1038/nm.4118

23. Oden L, Akbari M, Zaman T, Singer CF, Sun P, Narod SA, et al. Plasma osteoprotegerin and breast cancer risk in BRCA1 and BRCA2 mutation carriers. Oncotarget. (2016) 7:86687-94. doi: 10.18632/oncotarget.13417

24. Widschwendter M, Burnell M, Fraser L, Rosenthal AN, Philpott S, Reisel D, et al. Osteoprotegerin (OPG), the endogenous inhibitor of receptor activator of NF- $\kappa \mathrm{B}$ ligand (RANKL), is dysregulated in BRCA mutation carriers. EBioMed. (2015) 2:1331-9. doi: 10.1016/j.ebiom.2015.08.037

25. Cross SS, Harrison RF, Balasubramanian SP, Lippitt JM, Evans CA, Reed MW, et al. Expression of receptor activator of nuclear factor kappabeta ligand (RANKL) and tumour necrosis factor related, apoptosis inducing ligand (TRAIL) in breast cancer, and their relations with osteoprotegerin, oestrogen receptor, and clinicopathological variables. J Clin Pathol. (2006) 59:716-20. doi: 10.1136/jcp.2005.030031

26. Van Poznak C, Cross SS, Saggese M, Hudis C, Panageas KS, Norton L, et al. Expression of osteoprotegerin (OPG), TNF related apoptosis inducing ligand (TRAIL), and receptor activator of nuclear factor kappaB ligand (RANKL) in human breast tumours. J Clin Pathol. (2006) 59:56-63. doi: 10.1136/jcp.2005.026534

27. Santini D, Schiavon G, Vincenzi B, Gaeta L, Pantano F, Russo A, et al. Receptor activator of NF-kB (RANK) expression in primary tumors associates with bone metastasis occurrence in breast cancer patients. PLoS ONE. (2011) 6:e19234. doi: 10.1371/journal.pone.0019234

28. Owen S, Ye L, Sanders AJ, Mason MD, Jiang WG. Expression profile of receptor activator of nuclear-kappaB (RANK), RANK ligand (RANKL) and osteoprotegerin (OPG) in breast cancer. Anticancer Res. (2013) 33:199-206.

29. Sanger N, Ruckhaberle E, Bianchini G, Heinrich T, Milde-Langosch K, Muller V, et al. OPG and PgR show similar cohort specific effects as prognostic factors in ER positive breast cancer. Mol Oncol. (2014) 8:1196-207. doi: 10.1016/j.molonc.2014.04.003

30. Park HS, Lee A, Chae BJ, Bae JS, Song BJ, Jung SS. Expression of receptor activator of nuclear factor $\kappa-\mathrm{B}$ as a poor prognostic marker in breast cancer. $J$ Surg Oncol. (2014) 110:807-12. doi: 10.1002/jso.23737

31. Amin MB, Greene FL, Edge SB, Compton CC, Gershenwald JE, Brookland RK, et al. The eighth edition AJCC cancer staging manual: continuing to build a bridge from a population-based to a more "personalized" approach to cancer staging. CA Cancer J Clin. (2017) 67:93-9. doi: 10.3322/caac.21388

32. Labovsky V, Martinez LM, Davies KM, Garcia-Rivello H, Calcagno Mde L, Matas A, et al. Association between ligands and receptors related to the progression of early breast cancer in tumor epithelial and stromal cells. Clin Br Cancer. (2015) 15:e13-21. doi: 10.1016/j.clbc.2014.05.006

33. Labovsky V, Martinez LM, Davies KM, de Lujan Calcagno M, Garcia-Rivello $\mathrm{H}$, et al. Prognostic significance of TRAIL-R3 and CCR-2 expression in tumor epithelial cells of patients with early breast cancer. BMC Cancer. (2017) 17:280. doi: 10.1186/s12885-017-3259-8

34. Luo P, Lu G, Fan LL, Zhong X, Yang H, Xie R, et al. Dysregulation of TMPRSS3 and TNFRSF11B correlates with tumorigenesis and poor prognosis in patients with breast cancer. Oncol Rep. (2017) 37:2057-62. doi: 10.3892/or.2017.5449
35. Vidula N, Yau C, Li J, Esserman LJ, Rugo HS. Receptor activator of nuclear factor kappa B (RANK) expression in primary breast cancer correlates with recurrence-free survival and development of bone metastases in I-SPY1 (CALGB 150007/15 ACRIN 6657). Br Cancer Res Treat. (2017) 165:129-38. doi: $10.1007 /$ s10549-017-4318-1

36. Timotheadou E, Kalogeras KT, Koliou GA, Wirtz RM, Zagouri F, Koutras $A$, et al. Evaluation of the prognostic value of RANK, OPG, and RANKL mRNA expression in early breast cancer patients treated with anthracycline-based adjuvant chemotherapy. Transl Oncol. (2017) 10:589-98. doi: 10.1016/j.tranon.2017.05.006

37. Rachner TD, Kasimir-Bauer S, Gobel A, Erdmann K, Hoffmann O, Browne A, et al. Prognostic value of RANKL/OPG serum levels and disseminated tumor cells in nonmetastatic breast cancer. Clin Cancer Res. (2019) 25:1369-78. doi: 10.1158/1078-0432.CCR-18-2482

38. Weichhaus M, Segaran P, Renaud A, Geerts D, Connelly L. Osteoprotegerin expression in triple-negative breast cancer cells promotes metastasis. Cancer Med. (2014) 3:1112-25. doi: 10.1002/cam4.277

39. Chung ST, Geerts D, Roseman K, Renaud A, Connelly L. Osteoprotegerin mediates tumor-promoting effects of Interleukin-1beta in breast cancer cells. Mol Cancer. (2017) 16:27. doi: 10.1186/s12943-017-0606-y

40. Rachner TD, Schoppet M, Niebergall U, Hofbauer LC. 17beta-Estradiol inhibits osteoprotegerin production by the estrogen receptor-alpha-positive human breast cancer cell line MCF-7. Biochem Biophys Res Commun. (2008) 368:736-41. doi: 10.1016/j.bbrc.2008.01.118

41. de Groot AF, Appelman-Dijkstra NM, van der Burg SH, Kroep JR. The antitumor effect of RANKL inhibition in malignant solid tumors - A systematic review. Cancer Treat Rev. (2018) 62:18-28. doi: 10.1016/j.ctrv.2017.10.010

42. Yoldi G, Pellegrini P, Trinidad EM, Cordero A, Gomez-Miragaya J, SerraMusach J, et al. RANK signaling blockade reduces breast cancer recurrence by inducing tumor cell differentiation. Cancer Res. (2016) 76:5857-69. doi: 10.1158/0008-5472.CAN-15-2745

43. Goswami S, Sharma-Walia N. Osteoprotegerin secreted by inflammatory and invasive breast cancer cells induces aneuploidy, cell proliferation and angiogenesis. BMC Cancer. (2015) 15:935. doi: 10.1186/s12885-015-1837-1

44. Ottewell PD, Wang N, Brown HK, Fowles CA, Croucher PI, Eaton CL, et al. OPG-Fc inhibits ovariectomy-induced growth of disseminated breast cancer cells in bone. Int J Cancer. (2015) 137:968-77. doi: 10.1002/ijc.29439

45. Zinonos I, Luo KW, Labrinidis A, Liapis V, Hay S, Panagopoulos V, et al. Pharmacologic inhibition of bone resorption prevents cancer-induced osteolysis but enhances soft tissue metastasis in a mouse model of osteolytic breast cancer. Int J Oncol. (2014) 45:532-40. doi: 10.3892/ijo.201 4.2468

Conflict of Interest: The authors declare that the research was conducted in the absence of any commercial or financial relationships that could be construed as a potential conflict of interest.

Copyright (c) 2020 Geerts, Chopra and Connelly. This is an open-access article distributed under the terms of the Creative Commons Attribution License (CC BY). The use, distribution or reproduction in other forums is permitted, provided the original author(s) and the copyright owner(s) are credited and that the original publication in this journal is cited, in accordance with accepted academic practice. No use, distribution or reproduction is permitted which does not comply with these terms. 